\title{
B-Cell CLL/Lymphoma 9-Like Protein
}

National Cancer Institute

\section{Source}

National Cancer Institute. B-Cell CLL/Lymphoma 9-Like Protein. NCI Thesaurus. Code C132330.

B-cell CLL/lymphoma 9-like protein (1499 aa, 157 kDa) is encoded by the human BCL9L gene. This protein plays a role in the promotion of beta-catenin transcriptional activity. 